\section{Balansert fremstilling av opioidbehandling ved langvarig smerte}

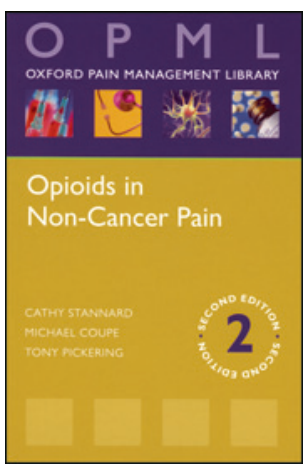

Cathy Stannard, Michael Coupe,

Tony Pickering

Opioids in non-cancer pain

2. utg. 112 s, tab, ill. Oxford: Oxford University

Press, 2013. Pris GBP 20

ISBN 978-0-19-967807-5

Dette er andre utgave av en liten, men viktig bok i serien Oxford Pain Management Library, skrevet av to erfarne klinikere og en nevrofarmakolog. Målgruppen er leger som i sin praksis behandler pasienter med langvarige smertetilstander.

Det var en dramatisk økning i forskrivning av opioide analgetika til «non-cancer pain» i USA for om lag 20 år siden. Dette førte til en epidemi av feilbruk og overdosedødsfall. Dette er bakgrunnen og motivasjonen for boken: Hvordan kan vi i Europa unngå feilene begått i USA og finne en optimal balanse i bruken av opioide analgetika?

Forfatterne gir korte og rimelig oppdaterte oversikter over farmakologi, farmakogenetikk, forskrivningstrender og anbefalt praksis for bruk av opioide analgetika. Andre kapitler omhandler positive effekter, kontraindikasjoner og bivirkninger. De omtaler grundig den erfaring at alle som må bruke opioider for kroniske smerter, blir fysisk avhengige, dvs. at de får abstinensplager og sterke smertegjennombrudd ved brå seponering. Men få utvikler den alvorlige biopsykososiale sykdommen addiksjon, som innebærer endret atferd.

De bruker tre kliniske eksempler på hvor vanskelig dette kan være for allmennleger og spesialister: smerter i nedre del av ryggen, artrosesmerter og nevropatiske smerter. Forfatterne veier for og imot og konkluderer med at ingen av disse tre smertetilstandene er gode indikasjoner for langvarig opioidbehandling.

For pasienter med dårlig smertelindring, mange bivirkninger og uryddig forbruk angis omtrentlige doser ved konvertering til metadon. Racemisk metadon har både MOP-agonistvirkning, som morfin, og en NMDA-antagonistvirkning, som ketamin, og kan derfor gi bedre smertelindring. Metadonkonvertering er krevende og bør i Norge helst være en oppgave for erfarne smertespesialister $i$ et flerfaglig miljø.

Et par feil skjemmer helhetsinntrykket. Det brukes gammel nomenklatur på de ulike opioidreseptorene. Dessverre påstås det at buprenorfin er antagonist mot andre opioide analgetika. Dette er en observasjon fra ikke-reproduserte forsøk med isolerte tarmpreparater fra rotter. Denne misforståelsen fører til at pasienter som bruker buprenorfin i LAR- sammenheng, får beskjed om ikke å ta sin LAR-medisin i forbindelse med operasjoner. Seponering av buprenorfin fører bare til større behov for morfin ved postoperative smerter enn når pasienten får lov til å fortsette med sin buprenorfin før, under og etter en operasjon.

Dette en viktig faktabok om bruk av opioide analgetika i smertemedisin. Den burde oversettes til norsk der de spesifikke, norske sidene ved opioidbehandling kan omtales.

Harald Breivik

Professor emeritus, Avdelinger for smertebehandling og anestesi Oslo universitetssykehus

\section{Hva legers følelser gjør med praksis}

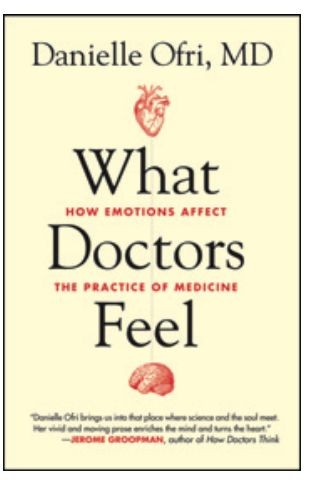

Danielle Ofri

What doctors feel

How emotions affect the practice of medicine. 224 s. Boston, MA: Beacon Press, 2013 Pris USD 25

ISBN 978-0-8070-7332-2

Når jeg bringer emner som legers sårbarhet, utilstrekkelighet og utrygghet på banen i studentundervisningen, opplever jeg stor interesse. At det er lov å føle seg mislykket, skamme seg og å gjenkjenne faresignaler som å fortie eller fortegne sannheten, eller unngå å møte pasienter man har forvoldt skade, vekker nysgjerrighet og spørsmål. Vi snakker ikke gjerne om våre nederlag. Ved studiet i Oslo måtte det letes lenge etter en kollega som ville stå frem og fortelle studentene om en stor faglig feil han hadde begått. Det gjør inntrykk.

Danielle Ofri jobber ved Bellevue Hospital i New York, et sykehus som tar seg av storbyens svakeste. Fra denne innsiktsposten har hun i fire bøker, gjennom fast spalte i New York Times og på lederplass i de største medisinske tidsskriftene gjort det til sin misjon å fortelle om legehverdagen, og hva pasientmøtene - og arbeidsmiljøene - gjør med oss.

I denne boken følger vi henne gjennom skjærsilden det første året som lege, skammen ved å gjøre feil, ydmykelsen ved å bli gjenstand for klager og nærmere undersøkelser, og gleden ved å gjøre en god jobb. Parallelt følger vi gjennom hele boken utfordringene og følelsene knyttet til behandlingen av en hjertesyk innvandrerkvinne uten rett til transplantasjon. Vi får høre historier om kolleger som havner i alkoholmisbruk eller trekker seg tilbake fra de mest belastende arbeidsområdene. Hun avlegger også kvalitetsbevegelsen en visitt, den er kritisk: Hun mener at mye av det som gjør en god lege, ikke kan måles, og hun spør om vi er tjent med nåværende tilnærming. Men fremfor alt forteller hun oss hvordan legenes følelser påvirker pasientarbeidet. Det vil vi helst ikke tenke på.

Boken er velskrevet, til en viss grad underbygd med relevante referanser, men er ikke en vitenskapelig tilnærming. Først og fremst gjør den nytte ved å sette temaet på dagsorden. Norske leger og studenter vil gjenkjenne mye, og fortellingene bør gi både trøst og refleksjon. Politikere og ledere i helsetjenesten kan få innsikt i hva som rører seg inni medlemmer av denne fra utsiden tilsynelatende så sterke og mektige profesjonen. For Legeforeningen og dens medlemmer kan boken fungere som en påminnelse om å skape rom for å ivareta alle legers følelser mens de er i daglig drift, før de selv blir pasienter.

Pål Gulbrandsen

Professor, Universitetet i Oslo 